\title{
FACTORS INFLUENCING ONLINE INFORMATION SEARCH AMONG DOCTORS WITH SPECIAL REFERENCE TO MEDICAL EQUIPMENTS
}

\author{
R S SATHYA SAMINADAN
}

Research Scholar \& Freelance Professor, LIBA, Chennai, Tamil Nadu, India

\begin{abstract}
The purpose of this study is to investigate and draw out factors influencing information search among doctors with special reference to medical equipments'. An attempt is made to highlight the traits of searching behaviour of doctors and information seeking before making a purchase decision through online for their professional requirement. The study followed qualitative and quantitative approach enquiry approach questionnaire in the form of survey. The data of the survey were analyzed to arrive at the findings of the study. The samples surveyed were all doctors from different practicing type. One clear understanding is that they seek information about the new advancements in the medical equipments they use for the professional needs. With growing importance of online sources, now a day's doctors are searching accurate and adequate information through various online sources for purchasing of medical equipments. This will help the companies for segmentation of markets properly and developing online marketing strategies to satisfy the expectations of doctors in purchasing of medical equipments through online. As the study focused on information seeking, searching behavior of doctors and factors that influence doctors the information search, some subjects among the sample were reluctant to participate initially and were not willing to part of the survey. However could manage to get 366 respondents to cooperate in the study. The subjects who eventually participated were from the same geographical locality thus reducing the generalizability of the findings.
\end{abstract}

KEYWORDS: Doctors, Factor Influencing Online Search, Search Behaviour \& Online Information

Received: Jul 10, 2017; Accepted: Jul 28, 2017; Published: Aug 16, 2017; Paper Id.: IJSMMRDAUG20177

\section{INTRODUCTION}

Technology and the Internet have fundamentally altered the way the world interacts and communicates. Through technology, doctors have more ways to interact with companies and brands, medical equipments and medicines and importantly, have many means for initiating these interactions that never existed less than couple of decades ago. Traditional approaches to branding that put emphasis on mass media techniques are less and less effective in a marketplace where doctors have access to massive amounts of information about brands, products, equipments and companies, and in which online sources have, in some cases, supplanted brand networks.

By looking at the enormous amount of online marketing campaigns, it appears that companies of all sizes have been translating their marketing approaches to the Internet because of its accessibility to their target audience and the money required to do so. As doctors are moving away from traditional media to new online sources, they have become more demanding; more time driven, more information and content intensive and highly 
individualistic. The nature of preferences and needs of doctors have created significant changes in information searching behaviour and actual purchasing behaviour as online sources facilitate information seeking and decision making for purchasing through online sources.

Currently, through online platforms the brand sends out a message and, from this point onwards it is up to doctors who brand messages they hope to share and edit and make a part of their "online" discussions and conversations. Thus, the market is relatively driven by preferences and recommendations, and as a result all brands and products are exposed to higher levels of inspection prior to purchase, influencing the decision- making process of doctors. Therefore, different online sources have various impacts on information searching behaviour

\section{STATEMENT OF THE PROBLEM}

The online sources not only offers companies the ability to communicate instantly with each doctors, but it also allows them to talk back, and that makes it possible for companies to customize offers and products. The proliferation of online sources gives doctors greater access to information and the means for communication and collaboration. The physical world is being replicated in the digital world through online communities, businesses and assets, fundamentally changing the way doctors engage with businesses and each other.

Doctors now have real-time, mobile access to data that they previously relied on brands to provide them with. Today's doctors have real-time access to competitive pricing information. In this way price transparency is increasing as doctors can compare the prices of products on the move, placing power firmly in their hand. Today's doctors trust each other more than they trust corporations and/or brands.

With more stimuli bombardments, doctors are more cautious and adopt in allocating attention to information; thus it is essential for marketers to find the reasons that speak to particular doctors' concerns, and to seek ways to speak to doctors individually, or in smaller communities.

With growing importance of online sources, companies have to understand not only information needs, searching behaviour, and purchase behaviour of doctors, but also the factors influencing online information search and their satisfaction and loyalty towards online sources and their satisfaction and loyalty towards online purchasing. This will help the companies for segmentation of markets properly and developing online marketing strategies to satisfy the expectations of doctors of online purchasing.

Singh (1998) found that 90 per cent of the respondents used the Internet for work related purposes and most of the respondents were recent users. Garrison (1998) identified many health related World Wide Web sites, introduced by libraries and groups representing doctors. He had created sets of guide lines or criteria that influenced the links they established. This was particularly true of sites that feature internet subject guides. However, there had not been a comprehensive set of evaluative criteria that users could use to filter out all but the most useful health information on the internet.

Voorbij (1999) revealed that the Web was being used primarily to search general, factual, ephemeral or very specific information. The study also showed that students and academicians faced many problems while searching the Web. Bavakutty and Salih (1999) showed that students, research scholars, and faculty members used the internet on education and research purpose. 


\section{LITERATURE REVIEW}

Laite (2000) showed that 57.60 per cent of the undergraduate students used the Internet 1-2 times per week and another 37.10 per cent used it 1-2 times daily. More than 50 per cent of the graduate students used Internet 1-2 times per week and 37.70 per cent used it 1-2 times daily. The results showed that the most used Internet service was e-mail. All the graduates and undergraduate students used e-mail services.

Mariyappagoudar and Jayashree (2000) discussed the growing importance and use of internet for information search and services as more and more services were being provided by many journal publishers' websites. Chandran (2000) indicated that more than 56 per cent of respondents were used to the internet to access information.

Panda and Sahu (2003) revealed that a majority of the colleges used the internet to provide online demonstrations to their students. Jagboro (2003) showed that the respondents used the internet to access research materials and for e-mail. The study concluded that the use of internet for academic activities would improve significantly with more access in departments.

\section{HYPOTHESES}

- There is no significant association between gender of doctors and preference of online sources

- There is no significant no significant association between educational qualification of doctors and preference of online sources.

- There is there is no significant association between location of the hospital and preference of online sources.

- There is no significant association between type of practice of doctors and preference of online sources.

\section{RESEARCH DESIGN}

The descriptive and exploratory research design is adopted for the present study.

\section{Study Area}

The present study is carried out in Chennai city.

\section{Study Period}

The study period for the research among doctors in Chennai pertains to 2016 - 17

\section{Population}

The population (total number of registered doctors) is 7763 doctors in Chennai city.

\section{Sampling Frame}

The sampling frame consists of all the doctors who are doing online purchasing

\section{Sampling Method}

The simple random sampling method is used for the present study.

\section{Sample Size}


The sample size for the present study is 366 doctors in Chennai city.

\section{Source of Primary Data}

The source of primary data is doctors in Chennai city.

\section{STEPS IN SAMPLING}

- Understanding the Marketing strategies of the Online Selling.

- Study the Medical industry and Medical equipments required for Hospital and Clinics.

- Collecting the information from self-constructed questionnaire.

- Focus on Online products, Searching behavior of Doctors, information needs of Doctors.

- $\quad$ Preparing questionnaire on the basis of above information.

- Gathering information from different source through Literature Review.

- On the basis of the response and the information gathered from other sources testing the Hypothesis.

\section{SAMPLING PROCEDURE}

- $\quad$ Primary Source: Questionnaire

- Secondary Source: Data through Internet, Articles and Case studies

The approach used is the survey method which is widely used for data collection and best suited for research. Questionnaire is structured base.

\section{DATA ANALYSIS AND INFERENCE}

\section{Time Spent for Online Search per Day}

The time spent for online search per day by doctors was analyzed and the results are presented in Table 6.1(i).

Table 6.1(i): Time Spent for Online Search per Day by Doctors

\begin{tabular}{|c|l|c|c|}
\hline Sl. No. & \multicolumn{1}{|c|}{ Time Spent } & Number of Doctors & Percentage \\
\hline 1. & One Hour & 70 & 19.12 \\
\hline 2. & Two Hours & 133 & 36.34 \\
\hline 3. & Three Hours & 117 & 31.97 \\
\hline 4. & More than Three Hours & 46 & 12.57 \\
\hline & Total & $\mathbf{3 6 6}$ & $\mathbf{1 0 0 . 0 0}$ \\
\hline
\end{tabular}

Source: Primary Data

The results show that 36.34 per cent of doctors spend two hours for online search per day, 31.97 per cent of doctors spend three hours for online search per day, 19.12 per cent of doctors spend one hour for online search per day and 12.57 per cent of doctors spend more than three hours for online search per day.

\section{Gender and Preference of Online Sources}

The association between gender of doctors and preference of online sources was analyzed and the results are presented in Table 6.2 (i). 
Table 6.2 (i): Gender and Preference of Online Sources

\begin{tabular}{|c|c|c|c|c|c|c|c|c|}
\hline \multirow[b]{2}{*}{$\begin{array}{c}\text { Sl. } \\
\text { No. }\end{array}$} & \multirow[b]{2}{*}{ Gender } & \multicolumn{6}{|c|}{ Online Sources } & \multirow[b]{2}{*}{ Total } \\
\hline & & Websites & $\begin{array}{c}\text { Online } \\
\text { Journals }\end{array}$ & E-Mails & $\begin{array}{c}\text { Search } \\
\text { Engines }\end{array}$ & $\begin{array}{l}\text { Social } \\
\text { Media }\end{array}$ & $\begin{array}{c}\text { E- } \\
\text { Books }\end{array}$ & \\
\hline 1. & Male & $\begin{array}{c}78 \\
(33.19)\end{array}$ & $\begin{array}{c}31 \\
(13.19)\end{array}$ & $\begin{array}{c}42 \\
(17.87)\end{array}$ & $\begin{array}{c}13 \\
(5.53)\end{array}$ & $\begin{array}{c}65 \\
(27.66)\end{array}$ & $\begin{array}{c}6 \\
(2.56)\end{array}$ & $\begin{array}{l}235 \\
(64.21)\end{array}$ \\
\hline 2. & Female & $\begin{array}{c}32 \\
(24.43)\end{array}$ & $\begin{array}{c}30 \\
(22.90)\end{array}$ & $\begin{array}{c}8 \\
(6.11)\end{array}$ & $\begin{array}{c}16 \\
(12.21)\end{array}$ & $\begin{array}{c}34 \\
(25.95)\end{array}$ & $\begin{array}{c}11 \\
(8.40)\end{array}$ & $\begin{array}{l}131 \\
(35.79)\end{array}$ \\
\hline & Total & $\begin{array}{c}110 \\
(30.05)\end{array}$ & $\begin{array}{c}61 \\
(16.67)\end{array}$ & $\begin{array}{c}50 \\
(13.66)\end{array}$ & $\begin{array}{c}29 \\
(7.92)\end{array}$ & $\begin{array}{c}99 \\
(27.05)\end{array}$ & $\begin{array}{c}17 \\
(4.65)\end{array}$ & $\begin{array}{l}366 \\
(100.00)\end{array}$ \\
\hline
\end{tabular}

To study the association between gender of doctors and preference of online sources, the Chi-Square test is applied and the results are presented in Table 6.2 (ii)

Table 6.2 (ii): Gender and Preference of Online Sources - Chi- Square

\begin{tabular}{|l|c|c|c|}
\hline & Value & Df & Sig \\
\hline Chi-Square & 26.444 & 5 & .000 \\
\hline
\end{tabular}

Source: Primary Data

The Chi-Square value of 26.444 is significant at one per cent level indicating that there is significant association between gender of doctors and preference of online sources. Hence, the null hypothesis of there is no significant association between gender of doctors and preference of online sources is rejected.

\section{Educational Qualification and Preference of Online Sources}

The association between educational qualification of doctors and preference of online sources was analyzed and the results are presented in Table 6.3 (i)

Table 6.3 (i): Educational Qualification and Preference of Online Sources

\begin{tabular}{|c|l|c|c|c|c|c|c|c|c|}
\hline \multirow{2}{*}{$\begin{array}{c}\text { SI. } \\
\text { No. }\end{array}$} & \multirow{2}{*}{$\begin{array}{c}\text { Educational } \\
\text { Qualification }\end{array}$} & Websites & $\begin{array}{c}\text { Online } \\
\text { Journals }\end{array}$ & $\begin{array}{c}\text { E- } \\
\text { Mails }\end{array}$ & $\begin{array}{c}\text { Search } \\
\text { Engines }\end{array}$ & $\begin{array}{c}\text { Social } \\
\text { Media }\end{array}$ & $\begin{array}{c}\text { E- } \\
\text { Books }\end{array}$ & Total \\
\cline { 3 - 9 } & M.B.B.S. & 38 & 17 & 16 & 15 & 36 & 8 & $\mathbf{1 3 0}$ \\
$(29.23)$ & $(13.08)$ & $(12.31)$ & $(11.54)$ & $(27.69)$ & $(6.15)$ & $(\mathbf{3 5 . 5 2})$ \\
\hline \multirow{2}{*}{2.} & M.D. & 36 & 13 & 14 & 10 & 32 & 7 & $\mathbf{1 1 2}$ \\
$(32.14)$ & $(11.61)$ & $(12.50)$ & $(8.93)$ & $(28.57)$ & $(6.25)$ & $(\mathbf{3 0 . 6 0 )}$ \\
\hline \multirow{2}{*}{3.} & M.S. & 21 & 28 & 3 & 4 & 14 & 2 & $\mathbf{7 2}$ \\
& & $(29.16)$ & $(38.89)$ & $(4.17)$ & $(5.56)$ & $(19.44)$ & $(2.78)$ & $(\mathbf{1 9 . 6 7})$ \\
\hline
\end{tabular}

Source: Primary Data

The figures in the parentheses are per cent to total

- Out of 130 doctors who have educational qualification of M.B.B.S., 29.23 per cent of doctors prefer websites followed by social media (27.69 per cent), online journals (13.08 per cent), e-mails (12.31 per cent), search engines (11.54 per cent) and e-books (6.15 per cent).

- Out of 112 doctors who have educational qualification of M.D., 32.14 per cent of doctors prefer websites followed by social media (28.57 per cent), e-mails (12.50 per cent), online journals (11.61 per cent), search engines (8.93 
per cent) and e-books (6.25 per cent).

- Out of 72 doctors who have educational qualification of M.S., 38.89 per cent of doctors prefer online journals followed by websites (29.16 per cent), social media (19.44 per cent), search engines (5.56 per cent), e-mails (4.17 per cent) and e-books (2.78 per cent).

- Out of 52 doctors who have other educational qualifications, 32.69 per cent of doctors prefer e-mails and social media followed by websites (28.85 per cent) and online journals (5.77 per cent).

To study the association between educational qualification of doctors and preference of online sources, the Chi-Square test is applied and the results are presented in Table 5.17.

Table 6.3 (ii): Educational Qualification and Preference of Online Sources - Chi- Square

\begin{tabular}{|l|c|c|c|}
\hline & Value & Df & Sig \\
\hline Chi-Square & 60.220 & 15 & .000 \\
\hline
\end{tabular}

Source: Primary Data

The Chi-Square value of 60.220 is significant at one per cent level indicating that there is significant association between educational qualification of doctors and preference of online sources. Hence, the null hypothesis of there is no significant association between educational qualification of doctors and preference of online sources is rejected.

\section{Location of the Hospital and Factors Influencing Online Information Search}

The relationship between location of the hospital and factors influencing online information search was analyzed and the results are presented in Table 6.4(i)

Table 6.4 (i): Location of the Hospital and Preference of Online Sources

\begin{tabular}{|c|c|c|c|c|c|c|c|c|}
\hline \multirow[b]{2}{*}{$\begin{array}{l}\text { Sl. } \\
\text { No. }\end{array}$} & \multirow[b]{2}{*}{$\begin{array}{l}\text { Location of } \\
\text { the Hospital }\end{array}$} & \multicolumn{6}{|c|}{ Online Sources } & \multirow[b]{2}{*}{ Total } \\
\hline & & Websites & $\begin{array}{l}\text { Online } \\
\text { Journals }\end{array}$ & $\begin{array}{c}\text { E- } \\
\text { Mails }\end{array}$ & $\begin{array}{c}\text { Search } \\
\text { Engines }\end{array}$ & $\begin{array}{l}\text { Social } \\
\text { Media }\end{array}$ & $\begin{array}{c}\text { E- } \\
\text { Books }\end{array}$ & \\
\hline 1. & Urban & $\begin{array}{c}35 \\
(23.18) \\
\end{array}$ & $\begin{array}{c}27 \\
(17.88) \\
\end{array}$ & $\begin{array}{c}26 \\
(17.22) \\
\end{array}$ & $\begin{array}{c}10 \\
(6.62) \\
\end{array}$ & $\begin{array}{c}47 \\
(31.13) \\
\end{array}$ & $\begin{array}{c}6 \\
(3.97) \\
\end{array}$ & $\begin{array}{c}151 \\
(41.26) \\
\end{array}$ \\
\hline 2. & Semi-Urban & $\begin{array}{c}56 \\
(43.08) \\
\end{array}$ & $\begin{array}{c}19 \\
(14.62)\end{array}$ & $\begin{array}{c}20 \\
(15.38) \\
\end{array}$ & $\begin{array}{c}12 \\
(9.23) \\
\end{array}$ & $\begin{array}{c}22 \\
(16.92) \\
\end{array}$ & $\begin{array}{c}1 \\
(0.77) \\
\end{array}$ & $\begin{array}{c}130 \\
(35.52) \\
\end{array}$ \\
\hline 3. & Sub-Urban & $\begin{array}{c}19 \\
(22.35)\end{array}$ & $\begin{array}{c}15 \\
(17.65) \\
\end{array}$ & $\begin{array}{c}4 \\
(4.71) \\
\end{array}$ & $\begin{array}{c}7 \\
(8.24) \\
\end{array}$ & $\begin{array}{c}30 \\
(35.29) \\
\end{array}$ & $\begin{array}{c}10 \\
(11.76) \\
\end{array}$ & $\begin{array}{c}85 \\
(23.22) \\
\end{array}$ \\
\hline & Total & $\begin{array}{c}110 \\
(30.05) \\
\end{array}$ & $\begin{array}{c}61 \\
(16.67) \\
\end{array}$ & $\begin{array}{c}50 \\
(13.66) \\
\end{array}$ & $\begin{array}{c}29 \\
(7.92) \\
\end{array}$ & $\begin{array}{c}99 \\
(27.05) \\
\end{array}$ & $\begin{array}{c}17 \\
(4.65) \\
\end{array}$ & $\begin{array}{c}366 \\
(100.00) \\
\end{array}$ \\
\hline
\end{tabular}

Source: Primary Data

The figures in the parentheses are per cent to total

- Out of 151 doctors who are working in the hospitals located in urban area, 31.13 per cent of doctors prefer social media followed by websites (23.18 per cent), e-mails (17.22 per cent), online journals (17.88 per cent), search engines (6.62 per cent) and e-books (3.97 per cent).

- Out of 130 doctors who are working in the hospitals located in semi-urban area, 43.08 per cent of doctors prefer websites followed by social media (16.92 per cent), e-mails (15.38 per cent), online journals (14.62 per cent), search engines ( 9.23 per cent) and e-books ( 0.77 per cent). 
- Out of 85 doctors who are working in the hospitals located in rural area, 35.29 per cent of doctors prefer social media followed by websites (22.35 per cent), online journals (17.65 per cent), e-books (11.76 per cent), search engines ( 8.24 per cent) and e-mails ( 4.71 per cent).

To study the association between location of the hospital and preference of online sources, the Chi-Square test is applied and the results are presented in Table 5.23.

Table 6.4 (ii): Location of the Hospital and Preference of Online Sources - Chi- Square

\begin{tabular}{|l|c|c|c|}
\hline & Value & df & Sig \\
\hline Chi-Square & 40.803 & 10 & .000 \\
\hline
\end{tabular}

Source: Primary Data

The Chi-Square value of 40.803 is significant at one per cent level indicating that there is significant association between location of the hospital and preference of online sources. Hence, the null hypothesis of there is no significant association between location of the hospital and preference of online sources is rejected.

\section{Type of Practice and Preference of Online Sources}

The association between type of practice of doctors and preference of online sources was analyzed and the results are presented in Table 6.5 (i).

Table 6.5 (i): Type of Practice and Preference of Online Sources

\begin{tabular}{|c|c|c|c|c|c|c|c|c|}
\hline \multirow[b]{2}{*}{$\begin{array}{l}\text { Sl. } \\
\text { No. }\end{array}$} & \multirow[b]{2}{*}{$\begin{array}{l}\text { Type of } \\
\text { Practice }\end{array}$} & \multicolumn{6}{|c|}{ Online Sources } & \multirow[b]{2}{*}{ Total } \\
\hline & & Websites & $\begin{array}{c}\text { Online } \\
\text { Journals }\end{array}$ & $\begin{array}{c}\text { E- } \\
\text { Mails }\end{array}$ & $\begin{array}{c}\text { Search } \\
\text { Engines }\end{array}$ & $\begin{array}{l}\text { Social } \\
\text { Media }\end{array}$ & $\begin{array}{c}\text { E- } \\
\text { Books }\end{array}$ & \\
\hline 1. & Pediatrician & $\begin{array}{c}43 \\
(26.22)\end{array}$ & $\begin{array}{c}24 \\
(14.63)\end{array}$ & $\begin{array}{c}20 \\
(12.19)\end{array}$ & $\begin{array}{c}18 \\
(10.98)\end{array}$ & $\begin{array}{c}50 \\
(30.49)\end{array}$ & $\begin{array}{c}9 \\
(5.49)\end{array}$ & $\begin{array}{c}164 \\
(44.81)\end{array}$ \\
\hline 2. & Specialist & $\begin{array}{c}38 \\
(41.76)\end{array}$ & $\begin{array}{c}4 \\
(4.40)\end{array}$ & $\begin{array}{c}15 \\
(16.48)\end{array}$ & $\begin{array}{c}6 \\
(6.59)\end{array}$ & $\begin{array}{c}22 \\
(24.18)\end{array}$ & $\begin{array}{c}6 \\
(6.59)\end{array}$ & $\begin{array}{c}91 \\
(24.86)\end{array}$ \\
\hline 3. & Surgeon & $\begin{array}{c}21 \\
(29.17)\end{array}$ & $\begin{array}{c}28 \\
(38.89) \\
\end{array}$ & $\begin{array}{c}3 \\
(4.17) \\
\end{array}$ & $\begin{array}{c}4 \\
(5.55) \\
\end{array}$ & $\begin{array}{c}14 \\
(19.44)\end{array}$ & $\begin{array}{c}2 \\
(2.78) \\
\end{array}$ & $\begin{array}{c}72 \\
(19.67)\end{array}$ \\
\hline 4. & Others & $\begin{array}{c}8 \\
(20.51) \\
\end{array}$ & $\begin{array}{c}5 \\
(12.82) \\
\end{array}$ & $\begin{array}{c}12 \\
(30.77) \\
\end{array}$ & $\begin{array}{c}1 \\
(2.57) \\
\end{array}$ & $\begin{array}{c}13 \\
(33.33) \\
\end{array}$ & $\begin{array}{c}0 \\
(0.00) \\
\end{array}$ & $\begin{array}{c}39 \\
(\mathbf{1 0 . 6 6 )}\end{array}$ \\
\hline & Total & $\begin{array}{c}110 \\
(30.05)\end{array}$ & $\begin{array}{c}61 \\
(16.67)\end{array}$ & $\begin{array}{c}50 \\
(13.66)\end{array}$ & $\begin{array}{c}29 \\
(7.92)\end{array}$ & $\begin{array}{c}99 \\
(27.05)\end{array}$ & $\begin{array}{c}17 \\
(4.65)\end{array}$ & $\begin{array}{c}366 \\
(100.00)\end{array}$ \\
\hline
\end{tabular}

Source: Primary Data

The figures in the parentheses are per cent to total

- Out of 164 doctors who are pediatricians, 30.49 per cent of doctors prefer social media followed by websites (26.22 per cent), online journals (14.63 per cent), e-mails (12.19 per cent), search engines (10.98 per cent) and ebooks (5.49 per cent).

- Out of 91 doctors who are specialists, 41.76 per cent of doctors prefer websites followed by social media (24.18 per cent), e-mails (16.48 per cent), search engines and e-books (6.59 per cent) and online journals ( 4.40 per cent),

- Out of 72 doctors who are surgeons, 38.89 per cent of doctors prefer online journals followed by websites (29.17 per cent), social media (19.44 per cent), search engines (5.55 per cent), e-mails (4.17 per cent) and e-books (2.78 per cent). 
- $\quad$ Out of 39 doctors who are other practitioners, 33.33 per cent of doctors prefer social media followed by e-mails (30.77 per cent), websites (20.51 per cent), online journals (12.82 per cent) and search engines (2.57 per cent).

To study the association between type of practice of doctors and preference of online sources, the Chi-Square test is applied and the results are presented in Table 5.27.

Table 6.5(ii): Type of Practice and Preference of Online Sources - Chi- Square

\begin{tabular}{|l|c|c|c|}
\hline & Value & Df & Sig \\
\hline Chi-Square & 60.858 & 15 & .000 \\
\hline
\end{tabular}

Source: Primary Data

The Chi-Square value of 60.858 is significant at one per cent level indicating that there is significant association between type of practice of doctors and preference of online sources. Hence, the null hypothesis of there is no significant association between type of practice of doctors and preference of online sources is rejected.

\section{Identification of Factors Influencing Online Information Search among Doctors}

To identify the factors influencing online information search among doctors, an exploratory factor analysis is done and the results are presented in Table 6.6(i). The Kaiser-Meyer-Olkin (KMO Test) measure of sampling adequacy $(\mathrm{KMO}=0.873)$ and Bartlett's test of Sphericity $($ Chi-square Value $=0.0024 ;$ Significance $=0.000)$ indicates that the factor analysis method is appropriate.

Three factors that are derived accounting for a total of 67.31 per cent of variations on 12 variables. Each of the three factors contributes to 31.81 per cent, 25.00 per cent and 10.50 per cent of variation respectively.

Table 6.6(i): Identification of Factors Influencing Online Information Search among Doctors

\begin{tabular}{|c|c|c|c|c|c|c|}
\hline Factor & Item & $\begin{array}{l}\text { Rotated } \\
\text { Factor } \\
\text { Loadings }\end{array}$ & $\begin{array}{l}\text { Eigen } \\
\text { Value }\end{array}$ & $\begin{array}{c}\% \text { of } \\
\text { Variation }\end{array}$ & $\begin{array}{l}\text { Cronbach's } \\
\text { Alpha }\end{array}$ & Factor Name \\
\hline \multirow{5}{*}{ I } & $\begin{array}{l}\text { I have good internet usage } \\
\text { skill }\end{array}$ & 0.63 & \multirow{5}{*}{3.90} & \multirow{5}{*}{31.81} & \multirow{5}{*}{0.84} & \multirow{5}{*}{ Efficiency } \\
\hline & $\begin{array}{l}\text { Online sources are easily } \\
\text { accessible }\end{array}$ & 0.70 & & & & \\
\hline & $\begin{array}{l}\text { Online sources are user } \\
\text { friendly }\end{array}$ & 0.69 & & & & \\
\hline & $\begin{array}{l}\text { Online sources are quick and } \\
\text { speed in transmission of } \\
\text { information }\end{array}$ & 0.71 & & & & \\
\hline & $\begin{array}{l}\text { Online sources are regularly } \\
\text { updated }\end{array}$ & 0.65 & & & & \\
\hline \multirow{4}{*}{ II } & $\begin{array}{l}\text { I get large quantity of } \\
\text { information from online } \\
\text { sources }\end{array}$ & 0.58 & \multirow{4}{*}{1.14} & \multirow{4}{*}{25.00} & \multirow{4}{*}{0.79} & \multirow{4}{*}{ Value } \\
\hline & $\begin{array}{l}\text { I have high level of } \\
\text { knowledge on online sources }\end{array}$ & 0.59 & & & & \\
\hline & $\begin{array}{l}\text { I get good quality of } \\
\text { information from online } \\
\text { sources }\end{array}$ & 0.56 & & & & \\
\hline & Online sources are reliable & 0.64 & & & & \\
\hline \multirow[t]{2}{*}{ III } & $\begin{array}{l}\text { Online sources are well } \\
\text { designed }\end{array}$ & 0.61 & \multirow[t]{2}{*}{1.04} & \multirow[t]{2}{*}{10.50} & \multirow[t]{2}{*}{0.86} & \multirow[t]{2}{*}{ Effectiveness } \\
\hline & Online sources are less risky & 0.63 & & & & \\
\hline
\end{tabular}




\begin{tabular}{|l|l|c|c|c|c|c|}
\hline & $\begin{array}{l}\text { Online sources are cost } \\
\text { effective compared to other } \\
\text { sources }\end{array}$ & 0.74 & & & \\
\hline & Cumulative \% of Variation & - & - & 67.31 & - & - \\
\hline & Overall & - & - & - & 0.83 & - \\
\hline
\end{tabular}

Source: Primary Data

Extraction Method: Principal Component Analysis.

Rotation Method: Varimax with Kaiser Normalization.

Rotation converged in 5 iterations.

Factor-I consists of they have good internet usage skill, online sources are easily accessible, online sources are user friendly, online sources are quick and speed in transmission of information and online sources are regularly updated. Hence, this factor is named as Efficiency.

Factor-II includes they get large quantity of information from online sources, they have high level of knowledge on online sources, they get good quality of information from online sources and online sources are reliable. Therefore, this factor is named as Value.

Factor-III comprises of online sources are well designed, online sources are less risky and online sources are cost effective compared to other sources. Thus, this factor is named as Effectiveness.

Overall Cronbach's Alpha value of the scale is 0.83 revealing that each measure exhibits acceptable level of internal consistency. Cronbach's Alpha value is varying from 0.86 for effectiveness to 0.79 for value. It is inferred that efficiency, value and effectiveness are the factors influencing online information search among doctors

\section{SUMMARY OF FINDINGS}

- $\quad 36.34$ per cent of doctors spend two hours for online search per day, 31.97 per cent of doctors spend three hours for online search per day, 19.12 per cent of doctors spend one hour for online search per day and 12.57 per cent of doctors spend more than three hours for online search per day.

- There is significant association between gender of doctors and preference of online sources.

- There is significant association between educational qualification of doctors and preference of online sources.

- There is significant association between location of the hospital and preference of online sources.

- There is significant association between type of practice of doctors and preference of online sources.

- Efficiency, value and effectiveness are the factors influencing online information search among doctors

\section{RESEARCH LIMITATIONS}

The present study is carried out in Chennai city only. The present study is based on the primary data collected from the doctors who are doing online purchasing. The drawbacks and limitations of the field level survey are very much applicable to the present research. The data collected from the doctors who are doing online purchasing are subjected to recall bias 


\section{DIRECTIONS FOR FUTURE RESEARCH}

Based on the hypotheses generated by the study the Future research can administer to a large number of respondents to validate the insights developed in this study. Further, the research could be extended across different locations to compare and contrast traits of searching behavior across different Locations.

\section{CONCLUSIONS}

The results showed the doctors do search for information to purchase the products online, and Gender, Location, Qualification and type of practice with definitely have impact on Searching behavior among doctors. Efficiency, Value and Effectiveness are the factors which influence online information search among doctors.

\section{REFERENCES}

1. Banerjee, I., Biswas, S., Biswas, A., De M Begum, S.A. and Haldar, S.,(2011), "Trends To Access Internet Among Medical Students of A Government Medical College in West Bengal”, Journal of Indian Med Association,109(7):pp.459-461.

2. Chudasama, R., Godara, N. and Srivastava, R.,(2008), “Assessing Computer Literacy and Attitude Towards E-Learning Among Final Year Medical Students", The Internet Journal of Medical Informatics, 5 (1): pp.11-32.

3. Fadeyi, A., Desalu, O.O., Ameen, A., Muhammed Adeboye, A.N.,(2010), "The Reported Preparedness and Disposition by Students in a Nigerian University towards the Use of Information Technology for Medical Education", Annals of African Medicine, 9(3):pp.129-134.

4. Krause, R., Moscati, R., Halpern, S., Schwartz, D.G. and Abbas, J., (2011), “Can Emergency Medicine Residents Reliably Use the Internet to Answer Clinical Questions?” Western Journal of Emergency Medicine, 12(4): pp.442-447.

5. Lal, P., Malhotra, R., Ahuja, C. and Ingle, G.K.,(2006), “Internet Use Among Medical Students and Residents of A Medical College of North India”, Indian Journal of Community Medicine, 31(4): pp.293-294.

6. Landrigan, C.P., Rothschild, J.M., Cronin, J.W., Kaushal, R., Burdick, E. and Katz J, T., (2004). “Effect of Reducing Interns' Work Hours on Serious Medical Errors in Intensive Care Units”, New England Journal of Medicine 35(1):pp.1838-1848.

7. Maroof KA, Parashar P and Bansal R. How are our medical students using the computer and internet? A study from a medical college of north India. Nigerian Medical Journal 2012; 53(2): 89-93.

8. Mony, P.K., George, K.C. and Chacko, N., (2004), “Computer Use Among Postgraduates of A Medical College In Southern India”, National Medical Journal of India, 17(3):pp.175-176.

9. Priyanka Manjari Behera, (2013), “Scholarly Use of Internet by the Faculty of Medical Sciences: An Evaluative Study”, IOSR Journal of Humanities and Social Science, 14(1):pp.10-14.

10. Romanov, K. and Aarnio, M, A., (2006), "Survey of the Use of Electronic Scientific Information Resources Among Medical and Dental Students”, Bio Med Central Medical Education, 9(6): pp.28-31.

11. Sanjeev Davey, Santosh Kumar Raghav, Anuradha Davey, Nirankar Singh and Singh, J.V.,(2014), “Internet Usage Patterns Among Medical Interns of Muzaffarnagar: A Comprehensive Survey Analysis”, Asian Journal of Medical Sciences, 6(2): pp. 99-104.

12. Selvi, M. and Dhanavandan, S.,(2012), “A Study on Utilization of Internet Resources and Tools by Basic Medical Science Professionals", Journal of Emerging Trends in Computing and Information Sciences, 3(12): pp. 1634-1637.

13. Thanuskodi, S., (2010)," Use of Internet and Electronic Resources for Medical Science Information: A Case Study”, Journal 
of Communication, 1(1): pp. 37-44.

14. Unnikrishnan, B., Kulshrestha, V, Saraf, A., Agrahari, A.C., Prakash, S., Samantaray. L, (2008), "Pattern of Computer and Internet Use Among Medical Students in Coastal South India. South East Asian Journal of Medical Education,2(2): pp.1-8

15. Voorbij, H., (1999), "Searching for Scientific Information on the Internet: A Dutch Academic User Survey”, Journal of the American Society for Information Science, 50(7):pp. 598-615 
